\title{
Effects of Post-mortem Temperature on the Physicochemical Properties of Hot-boned Chicken Breast Muscles
}

\author{
Long-Hao Yu', Eui-Soo Lee ${ }^{2}$, Jong-Youn Jeong ${ }^{3}$, Ji-Hun Choi ${ }^{4}$, and Cheon-Jei Kim ${ }^{4, *}$ \\ ${ }^{1}$ College of Food Science, H. L. J. August First Land Reclamation University, Daqing 163-319, China \\ ${ }^{2}$ National Institute of Animal Science RDA, Suwon 441-350, Korea \\ ${ }^{3}$ Muscle Biology and Meat Science, University of Wisconsin, Madison, WI 53706, USA \\ ${ }^{4}$ Department of Food Science and Biotechnology of Animal Resources, Konkuk University, \\ Seoul 143-701, Korea
}

\author{
사후 저장온도가 온도체 발골 육계 가슴육의 이화학적 특성에 미치는 영향 \\ Long-Hao $\mathrm{Yu}^{1} \cdot$ 이의수 ${ }^{2} \cdot$ 정종연 $^{3} \cdot$ 최지훈 ${ }^{4} \cdot$ 김천제 ${ }^{4, *}$ \\ ${ }^{1}$ College of Food Science, H. L. J. August First Land Reclamation University, China \\ 2농촌진흥청 축산과학원 \\ ${ }^{3}$ Muscle Biology and Meat Science, University of Wisconsin, Madison, WI 53706, USA \\ ${ }^{4}$ 건국대학교 축산식품생물공학전공
}

\begin{abstract}
The objective of this study was to examine the effects of high and low chilling temperature on the water-holding capacity (WHC) and tenderness of hot-boned breast meat of broiler chickens. Breast meat was obtained from 32 broiler chickens within 15 min post-mortem (PM), and then divided into two groups. One group was chilled at $-1^{\circ} \mathrm{C}$ and the other group was stored at $30^{\circ} \mathrm{C}$ for $3 \mathrm{hr}$, and then all the samples were chilled at $2^{\circ} \mathrm{C}$ until $24 \mathrm{hr}$ PM. During the storage, their physicochemical characteristics were tested at $15 \mathrm{~min}, 3 \mathrm{hr}$ and $24 \mathrm{hr}$ PM. These included pH, R-values, cooking losses, sarcomere length, MFI, and shear force of the breast meat, none of which was different $(p>0.05)$ between the two temperature treatments at $-1^{\circ} \mathrm{C}$ and $30^{\circ} \mathrm{C}$. However, sarcomere length was shortened more at $-1{ }^{\circ} \mathrm{C}$ than at $30^{\circ} \mathrm{C}$, MFI was larger at $30^{\circ} \mathrm{C}$ than at $-1^{\circ} \mathrm{C}$, drip loss was greater at $30^{\circ} \mathrm{C}$ than at $-1^{\circ} \mathrm{C}$, and WHC was lower at $30^{\circ} \mathrm{C}$ than at $-1^{\circ} \mathrm{C}(p<0.05)$. In brief, in terms of yield and tenderness, broiler breast meat stored at $-1^{\circ} \mathrm{C}$ was superior to that stored at $30^{\circ} \mathrm{C}$.
\end{abstract}

Key words : Hot-boning, broiler chicken, storage condition, physicochemical properties

\section{Introduction}

Post-mortem (PM) storage temperature is the most important factor influencing physicochemical changes in muscle, rigor degree, and ultimate meat quality. Many studies have been conducted on the influence of rigor temperature on muscle shrinkage, tenderness, and meat quality (Bendall, 1975; Honikel et al., 1986; Lee et al., 1979; Kang et al., 2006; Yu et al., 2005).

Hot-boning has many potential advantages: increased

*Corresponding author : Cheon Jei Kim, Department of Food Science and Biotechnology of Animal Resources, Konkuk University, Seoul 143-701, Korea. Tel: 82-2-450-3684, Fax: 82-2-444-6695, E-mail: kimcj@konkuk.ac.kr meat yield, energy saving, minimization of chiller space, reduced labor, and less time consumption (Pisula and Tyburcy, 1996). A lot of research has also been conducted to improve the process, e.g. to improve water-holding capacity (WHC), to enhance emulsification capacity (Fischer et al., 1979; Honikel and Hamm, 1978; Huffman et al., 1984; Sadler and Swan, 1997) and to reduce heat loss (Ray et al., 1980).

De Femery and Pool (1960) reported that storage of chicken meat at higher temperature $\left(37-41^{\circ} \mathrm{C}\right)$ immediately after slaughter can accelerate the rate of glycolysis and, then, complete rigor mortis earlier. Also, Briskey (1964) reported that lower $\mathrm{pH}$ caused by higher carcass temperature and rapid metabolism at the initial stage is the reason for excess protein denaturalization. Function 
depression of these denatured proteins is a major reason for reduction in WHC. The WHC of meat is very important because it directly influences the final yield and taste of meat products. A low WHC results in increased drip and cooking losses (Barbut, 1993; Froning et al., 1978; Northcutt et al., 1994). In addition, the rate of postmortem glycolysis is accelerated at high temperature. It also varies among different animals and muscles. Some muscles shrink considerably after slaughter at low temperature. Locker (1960) reported that rapid chilling of meat results in muscle contraction and tough meat: this phenomenon is called 'cold shortening'. Cold shortening occurs as calcium is released into sarcoplasm in an uncontrolled manner due to the rapid decrease in temperature, which causes the sarcoplasmic reticulum and mitochondria to lose their ability to retain calcium. An increase in free calcium while there is sufficient adenosine triphosphate (ATP) present (early PM) results in increased shortening of the sarcomeres (Huff-Lonergan et al., 2000). Muscle shrinkage reduces meat tenderness rapidly because sarcomere length is shortened by the overlapping of actin filaments in the center of the I-band and myosin filaments close to the Z-disk (Marsh and Carse, 1974). Therefore, the degree of muscle shrinkage with PM storage temperature has a crucial influence on meat tenderness (Marsh and Leet, 1966).

Many studies have been conducted on hot-boned pig and beef but few on chicken meat. Chicken has different properties from pork and beef in chemical constitution, muscle fiber type and distribution, and the rate of metabolism PM. It is, therefore, necessary to investigate the relationship between storage temperature of hotboned chicken meat and meat quality. The objective of this study was to evaluate chicken meats stored at either $-1^{\circ} \mathrm{C}$ or $30^{\circ} \mathrm{C}$ post-mortem, in order to understand the effect of storage temperature on meat quality and PM metabolism rate.

\section{Materials and Methods}

\section{Muscle sample preparation}

Thirty two commercially reared broilers (6 week of age and approximately 1.5-2.0 kg live weight) were obtained from a local poultry processor, transported to the Meat Science Laboratory at Konkuk University, and held overnight in order to minimize the effects of catching and handling. The birds were stunned electrically at $50 \mathrm{~V}$ for $10 \mathrm{sec}$ and killed by bleeding for approximately $2 \mathrm{~min}$ from a single unilateral neck cut severing the right carotid artery and jugular vein. Immediately after bleeding and peeling off skins, breast muscles were excised from the left and right sides of carcasses within 15 min PM. The separated left and right breast muscles were randomly assigned to one of five portions and each portion was packed with polyethylene bag. The first portion was used immediately to determine the physicochemical characteristics $(\mathrm{n}=25)$, and another two portions were placed at $-1^{\circ} \mathrm{C}$ for $3 \mathrm{hr}(\mathrm{n}=25)$ and then stored at $2^{\circ} \mathrm{C}$ until $24 \mathrm{hr}$ $(\mathrm{n}=25) \mathrm{PM}$. The other two portions were placed at $30^{\circ} \mathrm{C}$ for $3 \mathrm{hr}(\mathrm{n}=25)$ and then stored at $2^{\circ} \mathrm{C}$ until $24 \mathrm{hr}(\mathrm{n}=25)$ PM. After storing as previously stated, their physicochemical properties were evaluated.

\section{pH and R-value}

The $\mathrm{pH}$ of muscle samples was determined in triplicate using a modification of the iodoacetate method initially described by Jeacocke (1977). Approximately $2 \mathrm{~g}$ of sample was homogenized in $10 \mathrm{~mL}$ of iodoacetate solution (5 $\mathrm{mM}$ sodium iodoacetate, $150 \mathrm{mM}$ potassium chloride, and the $\mathrm{pH}$ adjusted to 7.0 with potassium hydroxide) with Ultra Turrax (Model No. T25, Janken and Kunkel, Germany) at 10,000 rpm for $1 \mathrm{~min}$, and the $\mathrm{pH}$ of the homogenate was determined using a $\mathrm{pH}$ meter (340, Mettler Toledo, Switzerland) calibrated at $\mathrm{pH} 4.0$ and 7.0. Rvalue was determined by a little modified method of the procedure of Koh et al. (1993). Four g of sample was homogenized in $6 \%$ perchlolic acid $\left(\mathrm{HClO}_{4}\right)$ at $5,000 \mathrm{rpm}$ for $90 \mathrm{sec}$, then centrifuged at 3,000 $\times \mathrm{g}$ for $10 \mathrm{~min}$. Ten $\mathrm{mL}$ of the supernatant was taken, and its $\mathrm{pH}$ was adjusted with $2 \mathrm{M} \mathrm{KOH}$ to $6.0-6.5$, then chilling-stored for $60 \mathrm{~min}$. Thereafter, it was filtrated with Whatman No.1 and 0.1 $\mathrm{mL}$ of the filtrated solution was mixed with $2.9 \mathrm{~mL}$ of 0.1 $\mathrm{M}$ phosphate buffer ( $\mathrm{pH}$ 6.5), and then its absorbance at 250 and $260 \mathrm{~nm}$ was determined with UV spectrophotometer (DU650, Beckman, USA). Then, R-value of $A_{250}$ $\mathrm{A}_{260}$ was calculated.

\section{Drip, cooking loss and total moisture loss}

The samples were stored for $3 \mathrm{hr}$ at $-1^{\circ} \mathrm{C}$ and $30^{\circ} \mathrm{C}$, respectively, and then transferred to $2^{\circ} \mathrm{C}$ until $24 \mathrm{hr}$, the drip, cooking loss and total moisture loss were determined. Drip loss was calculated according to weight loss percentage compared with the weight before storage. After drip loss determination, the samples were bagged with polyethylene and then immersed in a $75^{\circ} \mathrm{C}$ water bath (Model 10-101, Daehan Co., Korea) for $30 \mathrm{~min}$ and cooled at room temperature for $30 \mathrm{~min}$. After cooling to room temperature, the bags were opened and free juice 
was drained. The cooked samples were blotted with a paper towel and weighed. Cooking loss was determined by weighing the meat before and after cooking. Also, the total moisture loss for each treatment was determined as:

$$
\text { Total moisture loss }(\%)=\frac{\text { Cooked sample weight }}{\text { Raw muscle sample weight }} \times 100
$$

\section{Water-holding capacity (WHC)}

The water-holding capacity of PM muscle also provides information on the meat quality. Thus, WHC was measured at 1/4, 3 and $24 \mathrm{hr}$ PM by a modification of the procedure of Grau and Hamm (1953). Briefly, $300 \mathrm{mg}$ of sample muscle was placed in a filter press device and compressed for $3 \mathrm{~min}$. WHC was calculated from duplicate samples as a ratio of the meat film area to the total area; hence, a larger value suggests a higher WHC.

\section{Sarcomere length}

Sarcomere length was determined by the method (Voyle, 1971) with Helium-Neon-Laser diffraction (Model No.212-2, Spectra-physics, USA). At different time postmortem, 1-2 g of muscle samples were carefully cut with a knife and immerged in $2 \%$ glutaraldehyde solution with $2 \%$ glucose in a $0.1 \mathrm{M}$ phosphate buffer, $\mathrm{pH} 7.0$, at temperature similar to that at which the muscles were incubated, and sarcomere length was measured.

\section{Myofibrillar fragmentation index (MFI)}

Myofibrils were obtained according to the method of Olson et al. (1976) using MFI buffer (20 mM K $\mathrm{HPO}_{4} /$ $\mathrm{KH}_{2} \mathrm{PO}_{4}, \mathrm{pH}$ 7, $100 \mathrm{mM} \mathrm{KCl}, 1 \mathrm{mM}$ EDTA, $1 \mathrm{mM} \mathrm{NaN}_{3}$ ). The myofibrils were suspended in MFI buffer. An aliquot of myofibril suspension was diluted with the MFI buffer to $0.5 \mathrm{mg} / \mathrm{mL}$ protein concentration and the absorbance of this suspension was measured at $540 \mathrm{~nm}$. MFI values were recorded as absorbance units per $0.5 \mathrm{mg} / \mathrm{mL}$ myofibril protein concentration multiplied by 200 .

\section{Shear force}

For the determination of shear force, samples were cooked individually in plastic bags immersed in a $75^{\circ} \mathrm{C}$ water bath for $30 \mathrm{~min}$. The cooked meats were cooled and sampled at room temperature using a $12.7 \mathrm{~mm}$ circular core to determine shear force. Four sample cores were sheared from each sample across the length of the core with a Warner-Bratzler shear attachment (V-type blade set) on the texture analyzer (TA-XT2 $i$, Stable Micro Systems, England) under cross head speed of $2 \mathrm{~mm} / \mathrm{sec}$. Texture Expert for the WINDOWS ${ }^{\mathrm{TM}}$ operation system was used to analyze the data. The shear force value was the mean of the maximum forces required to shear each set of core samples and the units used for shear force were $\mathrm{kg}$.

\section{Statistical analysis}

The effect of temperature and post-mortem time was analyzed using the General Linear Model procedure of SAS System (SAS, 1996). Analysis of variance (ANOVA) and comparison of means by Duncan's multiple range test were made. Significant level $(p<0.05)$ was used in all the statistical tests.

\section{Results and Discussion}

\section{pH and R-value}

The changes of $\mathrm{pH}$ and $\mathrm{R}$-value of chicken breast meat held at $-1^{\circ} \mathrm{C}$ and $30^{\circ} \mathrm{C}$ for $3 \mathrm{hr}$ post-mortem (PM) after hot-boning are shown in Table 1 . The $\mathrm{pH}$ value for meat stored at both $-1^{\circ} \mathrm{C}$ and $30^{\circ} \mathrm{C}$ was 6.60 at 15 min PM. At $3 \mathrm{hr} \mathrm{PM} \mathrm{pH}$ values were 5.80 and 5.89, and at $24 \mathrm{hr} \mathrm{PM}$ they were 5.63 and 5.56, respectively. The rate of $\mathrm{pH}$ decline was high during the first $3 \mathrm{hr}$ PM for meat at both temperatures, whereas from 3 to $24 \mathrm{hr}$ PM there was only a slight decline. In other words, there was no significant difference in $\mathrm{pH}$ value between the meat stored at $-1^{\circ} \mathrm{C}$ and that stored at $30^{\circ} \mathrm{C}$. This result is in agreement with that of Lesiak et al. (1996), who reported that the rate of $\mathrm{pH}$ decline was high during the first hour PM for all tem-

Table 1. Changes of $\mathrm{pH}$ and $\mathrm{R}$-value of chicken breast muscle at different post-mortem temperature and storage time

\begin{tabular}{ccccc}
\hline \hline \multirow{2}{*}{ Traits } & Storage temperature & \multicolumn{3}{c}{ Time $(\mathrm{hr})$} \\
\cline { 3 - 5 } & $\left({ }^{\circ} \mathrm{C}\right)$ & $1 / 4$ & 3 & 24 \\
\hline \multirow{2}{*}{$\mathrm{pH}$} & -1 & $6.60 \pm 0.06^{\mathrm{a}}$ & $5.80 \pm 0.03^{\mathrm{b}}$ & $5.63 \pm 0.02^{\mathrm{c}}$ \\
& 30 & $6.60 \pm 0.06^{\mathrm{a}}$ & $5.89 \pm 0.05^{\mathrm{b}}$ & $5.56 \pm 0.03^{\mathrm{c}}$ \\
\hline \multirow{2}{*}{ R-value } & -1 & $0.91 \pm 0.01^{\mathrm{b}}$ & $1.21 \pm 0.03^{\mathrm{a}}$ & $1.27 \pm 0.05^{\mathrm{a}}$ \\
& 30 & $0.91 \pm 0.01^{\mathrm{c}}$ & $1.23 \pm 0.04^{\mathrm{b}}$ & $1.34 \pm 0.01^{\mathrm{a}}$ \\
\hline
\end{tabular}

Values are the Mean \pm SE.

${ }^{\mathrm{a}-\mathrm{c}}$ Means in the same row with different superscripts differ significantly $(p<0.05)$. 
peratures $\left(0^{\circ} \mathrm{C}, 12^{\circ} \mathrm{C}\right.$ and $\left.30^{\circ} \mathrm{C}\right)$ and a slight decline in $\mathrm{pH}$ from 3 to $24 \mathrm{hr}$ PM. The $\mathrm{pH}$ of turkey meat at $3 \mathrm{hr} \mathrm{PM}$ was not different among given various temperature treatments. In addition, Molette et al. (2003) observed that the ultimate $\mathrm{pH}$ of turkey meat stored after slaughter at 4,20 , and $40^{\circ} \mathrm{C}$ for $6 \mathrm{hr}$ and then stored at $4^{\circ} \mathrm{C}$ until 24 hr PM was not affected by the different temperature treatments, but that the $\mathrm{pH}$ value (about 5.8) was reached earlier in the $40^{\circ} \mathrm{C}$ treatment muscle than in the two other groups. Stewart et al. (1984) found that the $\mathrm{pH}$ decline of PM muscle appears to plateau after the fourth hour; there was no significant difference in $\mathrm{pH}$ between the muscle excised at $4 \mathrm{hr} \mathrm{PM}$ and that excised after $24 \mathrm{hr}$ (control muscle). However, Alvarado and Sams (2002) recounted that after evisceration, turkey carcasses chilled at 0,10 , 20 , and $30^{\circ} \mathrm{C}$ in agitated-immersion-water tanks for 45 min prior to deboning (60 min post-mortem) showed a more rapid $\mathrm{pH}$ decline in the muscle. The differences between these results were probably due to materials used and genetic factors.

$\mathrm{R}$-value can be used to measure the degree of adenosine nucleotides transformed into inosine nucleotides, and to estimates PM rigor development indirectly (Khan and Frey, 1971; Papa and Fletcher, 1988). As rigor mortis develops, R-value increases. R-value of broiler pectoralis major reaches 0.95-0.97 in 15-30 min PM, and reaches 1.2-1.3 in 2-4 hr PM (Papa and Fletcher, 1988).

In this experiment (Table 1), R-values of the meat stored at $-1^{\circ} \mathrm{C}$ for $15 \mathrm{~min}, 3$ and $24 \mathrm{hr}$ PM were 0.91, 1.21, and 1.27 , respectively. There were significant differences in R-value between $15 \mathrm{~min}$ and $3 \mathrm{hr} \mathrm{PM}(p<0.05)$, but not between $3 \mathrm{hr}$ and $24 \mathrm{hr} \mathrm{PM}(p>0.05)$. For the meat stored at $30^{\circ} \mathrm{C}$, R-values at $15 \mathrm{~min}, 3$ and $24 \mathrm{hr}$ were $0.91,1.23$, and 1.34, respectively, and showed significant differences among the various storage times $(p<0.05)$. R-values for meat at both temperatures at $3 \mathrm{hr}$ PM exceeded 1.2. These results are similar to those of Papa and Fletcher (1988). But R-value was not significantly different between the two storage temperatures $(p>0.05)$.

\section{Drip loss, cooking loss and water-holding capacity}

Drip loss, cooking loss and water-holding capacity (WHC) are shown in Table 2. Drip losses of meat stored at $-1{ }^{\circ} \mathrm{C}$ and $30^{\circ} \mathrm{C}$ for $3 \mathrm{hr} \mathrm{PM}$ were 0.30 and $0.94 \%$, and $1.00 \%$ and $1.84 \%$ for $24 \mathrm{hr}$, respectively. Significant differences were observed in results between 3 and $24 \mathrm{hr}$ $\mathrm{PM}$ and between meat stored at -1 and $30^{\circ} \mathrm{C}(p<0.05)$. These results are similar to those of Alvarado and Sams (2002), who found that the drip loss of muscles from turkey carcasses chilled at $30^{\circ} \mathrm{C}$ was significantly higher than that of those chilled at $0^{\circ} \mathrm{C}$ and $10^{\circ} \mathrm{C}$. Also, Lesiak et al. (1996) reported that there was a significant correlation between PM temperature and storage time in both breast and leg muscles for turkey breast where drip loss was the least at $0^{\circ} \mathrm{C}$ and $12^{\circ} \mathrm{C}$ and the largest at $30^{\circ} \mathrm{C}$. Our results also showed that the pre-rigor temperature of hot-boned meat has an important influence on drip loss. Generally, drip loss is an ongoing process involving the transfer of water from myofibrils to the extra-cellular space; it is affected by structural features at several levels within the muscle tissue (Bertram et al., 2002). Drip loss is associated with degradation of muscle proteins and shrinkage of the muscle PM (Kristensen and Purslow, 2001; Melody et al., 2004).

In this study (Table 2), cooking loss at 15 min after slaughter was $12.44 \%$ for both temperatures, and cooking losses at 3 and $24 \mathrm{hr}$ PM were 11.40 and $11.88 \%$, respectively, for meat stored at $-1^{\circ} \mathrm{C}$, and 12.52 and $11.19 \%$, respectively, for meat stored at $30^{\circ} \mathrm{C}$, but the differences were not significant. Geesink et al. (2000) observed that cooking loss of longissimus muscle in lamb was not affected by initial temperature treatment $\left(16 \mathrm{hr}, 5-35^{\circ} \mathrm{C}\right)$.

Table 2. Changes of drip loss, cooking loss and water-holding capacity (WHC) of chicken breast muscle at different post-mortem temperature and storage time

\begin{tabular}{ccccc}
\hline \hline \multirow{2}{*}{ Traits } & Storage temperature & \multicolumn{3}{c}{ Time (hr) } \\
\cline { 3 - 5 } & $\left({ }^{\circ} \mathrm{C}\right)$ & $1 / 4$ & 3 & 24 \\
\hline \multirow{2}{*}{ Drip loss $(\%)$} & -1 & - & $0.30 \pm 0.02^{\mathrm{b}, \mathrm{y}}$ & $1.00 \pm 0.15^{\mathrm{a}, \mathrm{y}}$ \\
& 30 & - & $0.94 \pm 0.07^{\mathrm{b}, \mathrm{x}}$ & $1.84 \pm 0.19^{\mathrm{a}, \mathrm{x}}$ \\
\hline \multirow{2}{*}{ Cooking loss (\%) } & -1 & $12.44 \pm 0.71$ & $11.40 \pm 0.48$ & $11.88 \pm 0.82$ \\
\hline \multirow{2}{*}{ WHC $(\%)$} & 30 & $12.44 \pm 0.71$ & $12.52 \pm 0.31$ & $11.19 \pm 0.82$ \\
\hline
\end{tabular}

Values are the Mean \pm SE.

${ }^{a-c}$ Means in the same row with different superscripts differ significantly $(p<0.05)$.

${ }^{\mathrm{x}, \mathrm{y}}$ Means in the same column with different superscripts differ significantly $(p<0.05)$. 
Muscles aged for $24 \mathrm{hr}$ had a higher cooked yield than those cooked immediately upon returning to the laboratory from the processing plant. McKee and Sams (1998) observed that PM storage temperature of $40^{\circ} \mathrm{C}$ increased the cooking loss of turkey breast fillets compared to $0^{\circ} \mathrm{C}$ treatment. However, the differences between these results were probably due to materials used, genetic factors, and experimental design.

WHC decreased significantly with the increase of storage time $(p<0.05)$. In comparison with capacity at 15 min PM, WHC at 3 and $24 \mathrm{hr}$ PM was reduced by 20.8 and $30.7 \%$, respectively, for meat stored at $-1{ }^{\circ} \mathrm{C}$; it was reduced by 23.5 and $34.4 \%$, respectively, for meat stored at $30^{\circ} \mathrm{C}$. In addition, WHC at $24 \mathrm{hr}$ PM was $12.5 \%$ lower than that at $3 \mathrm{hr}$ PM for meat stored at $-1^{\circ} \mathrm{C}$ treatments and $16.55 \%$ lower than that at $3 \mathrm{hr} \mathrm{PM}$, for meat stored at $30^{\circ} \mathrm{C}$. However, there were no significant differences between temperatures during storage periods. Kristensen and Purslow (2001) observed that the WHC of meat decreases from $3.9 \%$ water loss at 1 day PM to $11.9 \%$ at 3 days PM.

\section{Sarcomere length, MFI, and shear force}

Changes of sarcomere length, myofibrillar fragmentation index (MFI) and shear force are shown in Table 3. For meats stored at $-1^{\circ} \mathrm{C}$, sarcomere length decreased significantly $(p<0.05)$ until $3 \mathrm{hr}$ PM, but did not decrease significantly thereafter $(p>0.05)$. However, for meats stored at $30^{\circ} \mathrm{C}$, sarcomere length at $3 \mathrm{hr}$ PM was not significantly different from that at $15 \min$ PM $(p>0.05)$, but sarcomere length at $24 \mathrm{hr}$ PM was significantly shorter than that at $3 \mathrm{hr}$ PM $(p<0.05)$. In addition, sarcomere for meat stored at $30^{\circ} \mathrm{C}$ for $3 \mathrm{hr}$ had less shrinkage than that for meat stored at $-1^{\circ} \mathrm{C}$. The results show that sarcomere of chicken meat stored at $-1^{\circ} \mathrm{C}$ and $30^{\circ} \mathrm{C}$ shrank continuously until $24 \mathrm{hr}$ PM. For the meat stored at $-1^{\circ} \mathrm{C}$, sar- comere lengths for meat stored for $3 \mathrm{hr}$ and $24 \mathrm{hr}$ PM were, respectively, $13 \%$ and $17 \%$ shorter than that at 15 min PM whereas those for meat stored at $30^{\circ} \mathrm{C}$ for 3 and $24 \mathrm{hr}$ PM were, respectively, 3.2 and $12 \%$ shorter than that at 15 min PM. This indicated that sarcomere length shrunk severely at $-1^{\circ} \mathrm{C}$ compared with that at $30^{\circ} \mathrm{C}$.

Lesiak et al. (1996) reported that the sarcomere length of turkey thigh meats stored at 0 and $30^{\circ} \mathrm{C}$ was both 0.27 $\mu \mathrm{m}$, whereas that of breast meat was $0.13 \mu \mathrm{m}$. Although it did not shrink as severely as beef did at low temperatures, poultry thigh meat (which contains more red-myofibril) is more sensitive to low temperature shrinkage than breast meat. In addition, other reports about sarcomere length in poultry measured under similar post-mortem storage conditions showed that the shrinkage of sarcomere length at $0^{\circ} \mathrm{C}$ was more severe (Dunn et al., 1995; Papa and Fletcher, 1986) consistent with our results.

In our study, tenderness was expressed by measuring the MFI and shear force values (Table 3). MFI increased significantly with the increase of time in storage $(p<$ 0.05). However, no significant difference in MFI was found between meat stored at -1 and $30^{\circ} \mathrm{C}$. Kim et al. (1996) reported that MFI in chicken breast meat stored at $5^{\circ} \mathrm{C}$ after slaughter increased slightly until $6 \mathrm{hr}$ PM and thereafter it increased rapidly until $12 \mathrm{hr}$ PM, and then most of myofibrillars were fragmented by $24 \mathrm{hr}$ PM.

Shear force for meat stored at $-1^{\circ} \mathrm{C}$ increased from 8.82 $\mathrm{kg}$ at $15 \mathrm{~min}$ after slaughter to $9.93 \mathrm{~kg}$ at $3 \mathrm{hr}$, but the difference was not significant $(p>0.05)$. Shear force then decreased to $6.13 \mathrm{~kg}$ at $24 \mathrm{hr} \mathrm{PM}(p<0.05)$. For meat stored at $30^{\circ} \mathrm{C}$, shear forces increased at $3 \mathrm{hr}(p<0.05)$ but decreased $(p<0.05)$ at $24 \mathrm{hr}$ PM.

Wyche and Goodwin (1974) investigated the shear force of broiler meat during the $24 \mathrm{hr}$ PM. Their results revealed that shear force increased gradually until $4 \mathrm{hr}$ PM and thereafter decreased until $8 \mathrm{hr}$ PM, and then

Table 3. Changes of sarcomere length, myofibrillar fragmentation index (MFI) and shear force of chicken breast muscle at different post-mortem temperature and storage time

\begin{tabular}{|c|c|c|c|c|}
\hline \multirow{2}{*}{ Variables } & \multirow{2}{*}{$\begin{array}{c}\text { Storage temperature } \\
\left({ }^{\circ} \mathrm{C}\right)\end{array}$} & \multicolumn{3}{|c|}{ Time (hr) } \\
\hline & & $1 / 4$ & 3 & 24 \\
\hline \multirow{2}{*}{ Sarcomere length $(\mu \mathrm{m})$} & -1 & $1.85 \pm 0.03^{\mathrm{a}}$ & $1.61 \pm 0.05^{\mathrm{b}, \mathrm{y}}$ & $1.54 \pm 0.04^{\mathrm{b}}$ \\
\hline & 30 & $1.85 \pm 0.03^{\mathrm{a}}$ & $1.79 \pm 0.08^{\mathrm{a}, \mathrm{x}}$ & $1.63 \pm 0.04^{\mathrm{b}}$ \\
\hline \multirow{2}{*}{ MFI } & -1 & $70.20 \pm 1.79^{c}$ & $79.75 \pm 2.46^{b}$ & $98.75 \pm 2.69^{\mathrm{a}}$ \\
\hline & 30 & $70.20 \pm 1.79^{c}$ & $81.99 \pm 2.36^{b}$ & $104.43 \pm 4.00^{\mathrm{a}}$ \\
\hline \multirow{2}{*}{ Shear force $(\mathrm{kg})$} & -1 & $8.82 \pm 0.78^{a}$ & $9.93 \pm 0.41^{\mathrm{a}}$ & $6.13 \pm 0.46^{\mathrm{b}}$ \\
\hline & 30 & $8.82 \pm 0.78^{b}$ & $11.03 \pm 0.70^{\mathrm{a}}$ & $5.38 \pm 0.03^{\mathrm{c}}$ \\
\hline
\end{tabular}

Values are the Mean \pm SE.

${ }^{a-c}$ Means in the same row with different superscripts differ significantly $(p<0.05)$.

${ }^{\mathrm{x}, \mathrm{y}}$ Means in the same column with different superscripts differ significantly $(p<0.05)$. 
increased again slightly but not significantly. Similarly, the shear force of raw meat did not change significantly when turkey pectoralis major meat was individually stored at 4,20 , and $40^{\circ} \mathrm{C}$ for $6 \mathrm{hr}$ and then all stored at $4^{\circ} \mathrm{C}$ for $18 \mathrm{hr}$ (Molette et al., 2003). McKee and Sams (1998) determined shear forces of broiler breast meats stored at 0,20 , and $40^{\circ} \mathrm{C}$ until $4 \mathrm{hr} \mathrm{PM}$ then refrigerated until $24 \mathrm{hr}$ PM. It was found that there were no significant differences between 0 and $20^{\circ} \mathrm{C}$ and between 20 and $40^{\circ} \mathrm{C}$, but there were significant differences between meat stored at $0^{\circ} \mathrm{C}$ and that stored at $40^{\circ} \mathrm{C}$.

As mentioned above, this study was to use (short rigor mortis time) white meats unlike red meats such as beef and pork. Broilers stored at $-1^{\circ} \mathrm{C}$ had lower drip loss and shear force but had shorter sarcomere length than those stored at $30^{\circ} \mathrm{C}$. In the meat of big livestock such as beef and pork, cold shortening is distinctly distinguished from heat shortening in general (Hertzman et al., 1993), whereas there is little difference between the two in the meat of small livestock such as poultry (Wyche and Goodwin, 1974). The results of this study, therefore, cannot be similar to results from big livestock. In brief, in terms of yield and tenderness, broiler breast meats stored at $-1{ }^{\circ} \mathrm{C}$ were superior to meats stored at $30^{\circ} \mathrm{C}$.

\section{Acknowledgement}

This study was supported by Technology Development Program (608001-05-1-SB410) for Agriculture and Forestry, Ministry for Agriculture, Forestry and Fisheries, Republic of Korea. The authors also partially supported by the Brain Korean 21 (BK21) Project from Ministry of Education and Human Resources Development.

\section{References}

1. Alvarado, C. Z. and Sams, A. R. (2002) The role of carcass chilling rate in the development of pale, exudative turkey pectoralis. Poult. Sci. 81, 1365-1370.

2. Barbut, S. (1993) Colour measurements for evaluating the pale soft exudative (PSE) occurrence in turkey meat. Food Res. Int. 26, 39-43.

3. Bendall, J. R. (1975) Cold-contracture and ATP-turnover in the red and white musculature of the pig postmortem. J. Sci. Food Agric. 26, 55-71.

4. Bertram, H. C., Purslow, P. P., and Andersen, H. J. (2002) Relationship between meat structure, water mobility, and distribution: A low-field nuclear magnetic resonance study. J. Agric. Food Chem. 50, 824-829.

5. Briskey, E. J. (1964) Etiological status and associated studies of pale, soft, exudative porcine musculature. Adv. Food Res.
13, 89-105.

6. De Femery, D. and Pool, M. F. (1960) Biochemistry of chicken muscle as related to rigor-mortis and tenderization. Food Res. 25, 73-87.

7. Dunn, A. A., Kilpatrick, D. J., and Gault, N. S. F. (1995) Contribution of rigor shortening and cold shortening to variability in the texture of Pectoralis major muscle from commercially-processed broilers. Br. Poult. Sci. 36, 401-413.

8. Fischer, C., Hamm, R., and Honikel, K.O. (1979) Changes in solubility and enzymatic activity of muscle glycogen phosphorylase in PSE muscles. Meat Sci. 3, 11-19.

9. Froning, G. W., Babji, A. S., and Mather, F. B. (1978) The effect of preslaughter temperature, stress, struggle and anesthetization on color and textural characteristic of turkey muscle. Poult. Sci. 57, 630-633.

10. Geesink, G. H., Bekhit, A. D., and Bickerstaffe, R. (2000) Rigor temperature and meat quality characteristics of lamb longissimus muscle. J. Anim. Sci. 78, 2842-2848.

11. Grau, R., and Hamm, R. (1953) Eine einfache methode zur bestimmung der wasserbindung im muskel. Naturwissenschaften, 40, 29-30.

12. Hertzman, C., Olsson, U., and Tornberg, E. (1993) The influence of high temperature, type of muscle and electrical stimulation on the course of rigor, ageing and tenderness of beef muscles. Meat Sci. 35, 119-141.

13. Honikel, K. O. and Hamm, R. (1978) Influence of cooling and freezing of minced pre-rigor muscle on the breakdown of ATP and glycogen. Meat Sci. 2, 181-188.

14. Honikel, K. O., Kim, C. J., Hamm, R., and Roncales, P. (1986) Sarcomere shortening of pre-rigor muscles and its influence on drip loss. Meat Sci. 16, 267-282.

15. Huff-Lonergan, E., Lonergan, S. T., and Vaske, L. (2000) pH relationships to quality attributes: tenderness. Proceed. 53rd Annual Reciprocal Meat Conference. Columbus, Ohio, USA, pp. 1-4.

16. Huffman, D. L., McCafferty, D. M., Cordray, J. C., and Stanley, M. H. (1984) Restructured beef steaks from hot-boned and cold-boned carcasses. J. Food Sci. 49, 164-167.

17. Jeacocke, R. E. (1977) Continuous measurements of the $\mathrm{pH}$ of the beef muscle in intact beef carcasses. J. Food Technol. 12, 375-386.

18. Kang, G. H., Jeong, J. Y., Ali, S., Kim, S. H., Jang, E. G., Kang, H. S. Lee, D. S., Lee, S. J., Park, G. B., and Joo, S. T. (2006) Effect of boning time and storage temperature on meat quality of duck breast. Korean J. Food Sci. Ani. Resour. 26, 43-48.

19. Khan, A. W. and Frey, A. R. (1971) A simple method for following rigor mortis development in beef and poultry meat. Can. Inst. Food Technol. J. 4, 139-142.

20. Kim, O. H., Park, C. I., and Park, Y. S. (1996) Effect of chitosan additive feeding on the tenderness of broiler meat. Korean J. Food Sci. Ani. Resour. 16, 62-66.

21. Koh, K. C., Binder, T. D., McMillan, K. W., and Kim, M. B. (1993) The relationship between ATP and R-values in postmortem bovine longissimus dorsi muscle. Meat Sci. 33, 253263. 
22. Kristensen, L. and Purslow, P. P. (2001) The effect of ageing on the water-holding capacity of pork: role of cytoskeletal proteins. Meat Sci. 58, 17-23.

23. Lee, Y. B., Hargus, G. L., Webb, J. E., Rickansrud, D. A., and Hagberg, E. C. (1979) Effect of electrical stimulation on postmortem biochemical changes and tenderness in broiler breast muscle. J. Food Sci. 44, 1121-1122.

24. Lesiak, M. T., Olson, D. G., Lesiak, C. A., and Ahn, D. U. (1996) Effects of postmortem temperature and time on the water-holding capacity of hot-boned turkey breast and thigh muscle. Meat Sci. 43, 51-60.

25. Locker, R. H. (1960) Degree of muscular contraction as a factor in tenderness of beef. J. Food Sci. 25, 304-307.

26. Marsh, B. B. and Carse, W. A. (1974) Meat tenderness and the sliding-filament hypothesis. J. Food Technol. 9, 129-139.

27. Marsh, B. B. and Leet, N. G. (1966) Studies in meat tenderness. III. The effects of cold shortening on toughness. $J$. Food Sci. 31, 450-459.

28. McKee, S. R. and Sams, A. R. (1998). Rigor mortis development at elevated temperatures induces pale exudative turkey meat characteristics. Poult. Sci. 77, 169-174.

29. Melody, J. L., Lonergan, S. M., Rowe, L. J., Huiatt, T. W., Mayes, M. S., and Huff-Lonergan, E. (2004) Early postmortem biochemical factors influence tenderness and waterholding capacity of three porcine muscles. J. Anim. Sci. 82, 1195-1205.

30. Molette, C., Rémignon, H., and Babilé, R. (2003) Maintaining muscles at a high post-mortem temperature induces PSElike meat in turkey. Meat Sci. 63, 525-532.

31. Northcutt, J. K., Foegeding, E. A., and Edens, F. W. (1994) Water-holding properties of thermally preconditioned chicken breast and leg meat. Poult. Sci. 73, 308-316.

32. Olson, D. G., Parrish, F. C. Jr., and Stromer, M. H. (1976) Myofibril fragmentation and shear resistance of three bovine muscles during postmortem storage. J. Food Sci. 41, 10361041.

33. Papa, C. M. and Fletcher, D. L. (1986) The effect of temperature on rigor development in broiler breast muscle (Abstr). Poult. Sci. 65(supplement 1), 186-187.

34. Papa, C. M. and Fletcher, D. L. (1988) Pectoralis muscle shortening and rigor development at different locations within the broiler breast. Poult. Sci., 67, 635-640.

35. Pisula, A. and Tyburcy, A. (1996) Hot Processing of Meat. Meat Sci., 43(Supplement 1), S125-S134.

36. Ray, F. E., Stiffler, D. M., and Berry, B. W. (1980) Effects of hot-boning and cooking method upon physical changes, cooking time and losses, and tenderness of beef roasts. $J$. Food Sci. 45, 769-772.

37. Sadler, D. N. and Swan, J. E. (1997) Chilled storage life of hot-boned, pre-rigor, salted minced beef. Meat Sci. 45, 427437.

38. SAS (1996) SAS/STAT Software for PC. Release 6.11, SAS Institute Inc., Cary, NC, USA.

39. Stewart, M. K., Fletcher, D. L., Hamm, D., and Thomson, J. E. (1984) The influence of hot-boning broiler breast muscle on $\mathrm{pH}$ decline and toughening. Poult. Sci. 63, 1935-1939.

40. Voyle, C. A. (1971) Sarcomere length and meat quality. Proceed. 17th European Meeting of Meat Research Workers. Bristol, England. pp. 95-97.

41. Wyche, R. C. and Goodwin, T. L. (1974) Hot-cutting of broilers and its influence on tenderness and yield. Poult. Sci. 53, 1668-1675.

42. Yu, L. H., Lee, E. S., Jeong, J. Y., Paik, H. D., Choi, J. H., and Kim, C. J. (2005) Effects of thawing temperature on the physicochemical properties of pre-rigor frozen chicken breast and leg muscles. Meat Sci. 71, 375-382.

(Received 2008.11.7/Revised 2008.12.15/ Accepted 2009.1.13) 